Article

\title{
Biochemical and Molecular Characterization of PvNTD2, a Nucleotidase Highly Expressed in Nodules from Phaseolus vulgaris
}

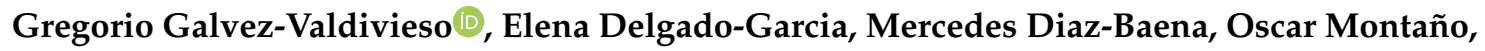 \\ Francisco A. Quiles, Manuel Pineda (D) and Pedro Piedras *(D) \\ Departamento de Botánica, Ecología y Fisiología Vegetal. Plants Molecular Physiology and Biotechnology \\ Group, Campus de Rabanales, Edif. Severo Ochoa, Universidad de Córdoba, 14071-Córdoba, Spain; \\ b32gavag@uco.es (G.G.-V.); b22degae@uco.es (E.D.-G.); b42dibam@uco.es (M.D.-B.); \\ oscarmonra92@gmail.com (O.M.); b42quluf@uco.es (F.A.Q.); bb1piprm@uco.es (M.P.) \\ * Correspondence: bb2pimop@uco.es; Tel.: +34-957-218-693
}

Received: 17 January 2020; Accepted: 28 January 2020; Published: 1 February 2020

\begin{abstract}
Nucleotides are molecules of great importance in plant physiology. In addition to being elementary units of the genetic material, nucleotides are involved in bio-energetic processes, play a role as cofactors, and are also components of secondary metabolites and the hormone cytokinin. The common bean (Phaseolus vulgaris) is a legume that transports the nitrogen fixed in nodules as ureides, compounds synthetized from purine nucleotides. The first step in this pathway is the removal of the 5 '-phosphate group by a phosphatase. In this study, a gene that codes for a putative nucleotidase (PvNTD2) has been identified in P. vulgaris. The predicted peptide contains the conserved domains for haloacid dehalogenase-like hydrolase superfamily. The protein has been overexpressed in Escherichia coli, and the purified protein showed molybdate-resistant phosphatase activity with nucleoside monophosphates as substrates, confirming that the identified gene codes for a nucleotidase. The optimum $\mathrm{pH}$ for the activity was 7-7.5. The recombinant enzyme did not show special affinity for any particular nucleotide, although the behaviour with AMP was different from that with the other nucleotides. The activity was inhibited by adenosine, and a regulatory role for this nucleoside was proposed. The expression pattern of PvNTD2 shows that it is ubiquitously expressed in all the tissues analysed, with higher expression in nodules of adult plants. The expression was maintained during leaf ontogeny, and it was induced during seedling development. Unlike PvNTD1, another NTD previously described in common bean, the high expression of PvNTD2 was maintained during nodule development, and its possible role in this organ is discussed.
\end{abstract}

Keywords: Phaseolus vulgaris; ureide synthesis; phosphatase; nucleotidase; nucleoside monophosphate; nodules

\section{Introduction}

Nucleotides are crucial compounds for plant metabolism and development. Purine and pyrimidine nucleotides are components of nucleic acids and, therefore, essentials for genetic information storage and for the machinery required for protein synthesis. Nucleotides are also components of vitamins and coenzymes and are important as energy donor molecules [1]. Purine nucleotides have a relevant role as precursors of ureides in the ureidic legumes such as soybeans and the common bean. These plants transport most of the nitrogen fixed in the nodules to the upper parts of the plants as ureides; therefore, purine nucleotide metabolism is crucial in the nodules of these plants. Ureides have been implicated in other processes with high nutrient transport requirements, such as seedling development $[2,3]$ and 
leaf senescence [4]. Studies performed in the model plant Arabidopsis suggest a function for ureides in response to abiotic stresses such as dark stress [5], drought [6], and salt stress [6,7]. The accumulation of ureides in response to stress might suggest a role for these compounds as protectors against the effects of reactive oxygen species [8], and recently we have described a relationship between ureide metabolism and antioxidant activities in legume seedlings [9].

Nucleotide metabolism can be divided into three parts: de novo synthesis, salvage of nucleosides and nucleobases, and catabolism of purines and pyrimidines [1]. The salvage pathway can be important in tissues with low demand for purines, whereas de novo synthesis would be the main route for purine synthesis in highly purine-producing tissues as nodules [10]. The salvage and de novo synthesis pathways converge at the formation of nucleoside monophosphate. The first step in the catabolic pathway is the removal of the 5'-phosphate group catalysed by a phosphatase that hydrolyses the nucleotides into nucleosides. However, it is unclear if this step is catalysed only by one enzyme or if the dephosphorylation reactions of different nucleotides are facilitated by several enzymes. Furthermore, it is also unclear if this step is catalysed by a nonspecific acid phosphatase (EC 3.1.3.2) or a specific 5'-nucleotidase (EC 3.1.3.5). Nucleoside kinases catalyse the reverse reaction to $5^{\prime}$-nucleotidase, and these opposite reactions have been suggested for almost all the nucleotide-nucleoside pairs [11]. In this way, the balance between synthesis and degradation of nucleotides can be regulated by the ratio between the phosphatase and kinase activities [11]. The nucleotide pools must be adjusted to the differing needs during the phases of metabolism; therefore, regulatory mechanisms are used to coordinate the absolute and relative levels of purines and pyrimidines both between cells and between subcellular compartments, as well as the relative levels of mono-, di-, and triphosphate forms [1].

Previously, we have purified and characterised phosphatase activity from common bean seedlings with high affinity for nucleotides [12,13]. This activity is insensitive to the phosphatase inhibitor molybdate [14]. The sequence of the gene encoding the common bean nucleotidase, PvNTD1 [13], shows similarity to the phosphatase/nucleotidase from soybean nodules described by Penheiter and colleagues [15,16], to a phosphatase gene induced by wounding in poplar [17], and to some genes encoding vegetative storage proteins with antimicrobial activity identified in Arabidopsis [18]. All these genes belong to the haloacid dehalogenase (HAD) superfamily of hydrolases. The family members are identified by the presence of four short motifs with conserved catalytic domain, although the overall sequence identity between HAD phosphatases is very low [19]. Although the catalytic domain is more conserved, the catalysed reaction and substrate specificity are difficult to predict and need to be determined empirically. HAD phosphatases are a very large and ubiquitous class of enzymes found in all the three superkingdoms of life, and they have attracted increased medical interest because of the involvement of some members of this family in diseases such as cancer and cardiovascular, metabolic, and neurological disorders [20]. The loss of some HAD phosphatases causes hereditary disorders in humans, disagreeing with the traditional view of this family as metabolic phosphatases with relaxed substrate specificities and with housekeeping functions [20]. The knowledge about the function of the phosphatases from this family in plants is more limited, but several HAD superfamily members have been involved in the regulation of Pi homeostasis [21-23].

To better understand the complex family of nucleotidases in plants, we have cloned and characterised the gene encoding a new nucleotidase member of the HAD superfamily in Phaseolus vulgaris. In addition, we have analysed its expression pattern in different tissues and developmental stages discussing the differences with the other member of this family previously characterised.

\section{Results}

\subsection{Identification, Cloning, and Overexpression of PvNTD2}

To identify new phosphatases with high affinity for nucleotides, a tblastn using the PvNTD1 sequence (Phvul.004G174200) was conducted in the NCBI database in the Phaseolus vulgaris genome [24]. This search retrieved the PHAVU_011G182400g gene as the sequence with the highest similarity to 
PvNTD1, so it was called PvNTD2. The PvNTD2 full-length cDNA sequence is $1077 \mathrm{bp}$ long, with the largest coding sequence of $810 \mathrm{bp}$ encoding a 269 amino acid polypeptide with a predicted molecular weight of $30.6 \mathrm{kDa}$ (Figure 1). The prediction of the subcellular location with DeepLoc [25] indicates that PvNTD2 could be an extracellular soluble protein (probability 0.73), and a sequence analysis with signalP-5.0 [26] predicts a cleavage site between position 24 and 25 (probability 0.95). After processing the signal peptide, the protein would have a molecular weight of $27.8 \mathrm{kDa}$, an isoelectric point of 5.04, and a charge of -10.11 at $\mathrm{pH}$ 7.0. The level of identity between PvNTD1 and PvNTD2 is $47 \%$, and the alignment between these two sequences is shown in Figure 1. PvNTD2 contains the domains conserved for haloacid dehalogenase-like hydrolase superfamily [24] consisting of motifs I to IV (Figure 1). A tblastn search in the GENBANK database using the PvNTD2 amino acid sequence was performed to identify similar sequences. This analysis revealed the existence of similar sequences in several plant genomes (Table S1), which are annotated as acid phosphatases, but which have not been characterized yet.

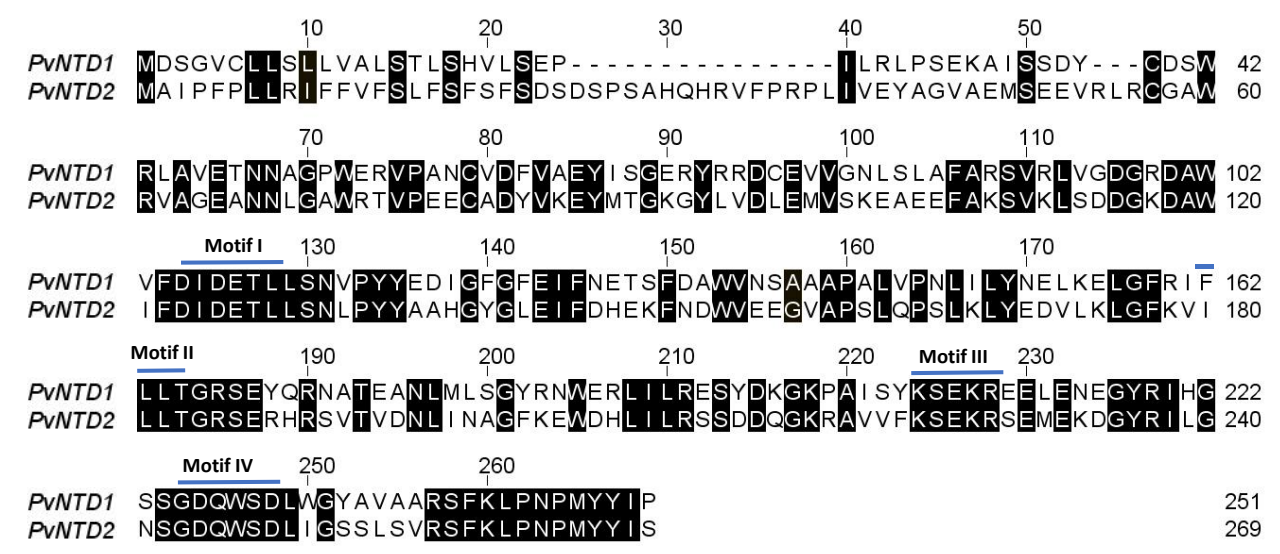

Figure 1. Alignment of amino acid sequences of PvNTD2 with the previously identified PvNTD1 [13]. Black boxes indicate the amino acids that are identical in both sequences. Motifs I to IV of the haloacid dehalogenase (HAD) superfamily [27] are indicated. Protein sequences were aligned using the ClustalW method.

The open reading frame of PvNTD2 without the predicted signal peptide was amplified by PCR, cloned into the vector pET30b (+), and transformed into Escherichia coli BL21 (DE3) cells. The expression of the His-tagged recombinant protein was induced by IPTG, and the protein extract of these cultures was analysed by SDS-PAGE showing a band of around $32 \mathrm{kDa}$ in both the soluble and the insoluble fractions, which indicates that part of the protein aggregates formed inclusion bodies. The soluble fraction was used to purify the recombinant protein by affinity chromatography with Ni sepharose (Figure 2). Apart from the expected protein, the antibodies revealed a second band with a molecular mass consistent with that of a dimer (Figure 2). 
A

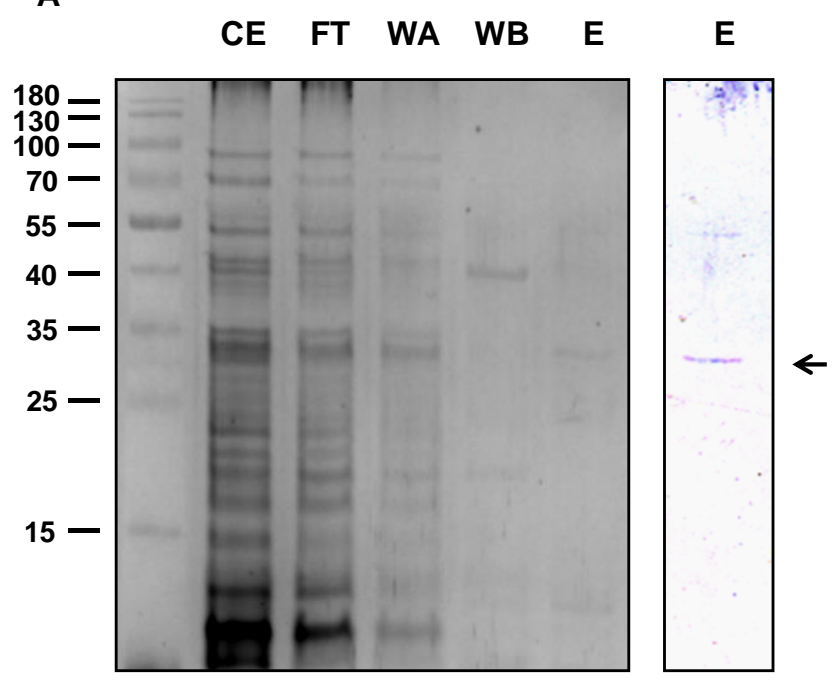

Figure 2. Purification of recombinant PvNTD2 from Escherichia coli. The purification process is indicated in Materials and Methods section. Lane CE: crude extracts, lane FT: proteins eluted from the column after loading the crude extract (unbound proteins), lane WA: proteins eluted from the column with washing buffer, lane WB: proteins eluted with washing buffer supplemented with $25 \mathrm{mM}$ imidazole, lane E: proteins eluted from the column after elution with $0.2 \mathrm{M}$ imidazole. (A). Samples were analysed by silver staining. (B) Samples were analysed by Western blot. The positions of the molecular weight markers are shown left of the figure.

\subsection{Protein Characterization}

The phosphatase activity was determined with several phosphorylated compounds at $\mathrm{pH} 7.0$ (Figure 3). The purified protein showed activity mainly with nucleoside monophosphates as substrates, whereas the activity determined with other phosphorylated compounds was minimal except for pNPP, an artificial compound used routinely to determine phosphatase activity. The activity was maximal when assayed with XMP, UMP, and TMP as substrates, and the specific activity of the purified protein was $4.1,3.9$, and $3.8 \mathrm{U} / \mathrm{mg}$, respectively. The activity with CMP, GMP, and IMP was slightly lower than that with the previously indicated substrates, with activity values of 3.0, 2.7, and 2.3, respectively, corresponding to $75 \%-60 \%$ of maximal activity. With AMP as substrate, the determined nucleotidase activity was only $0.7 \mathrm{U} / \mathrm{mg}$, which was the lowest among all the assayed nucleosides monophosphate. 


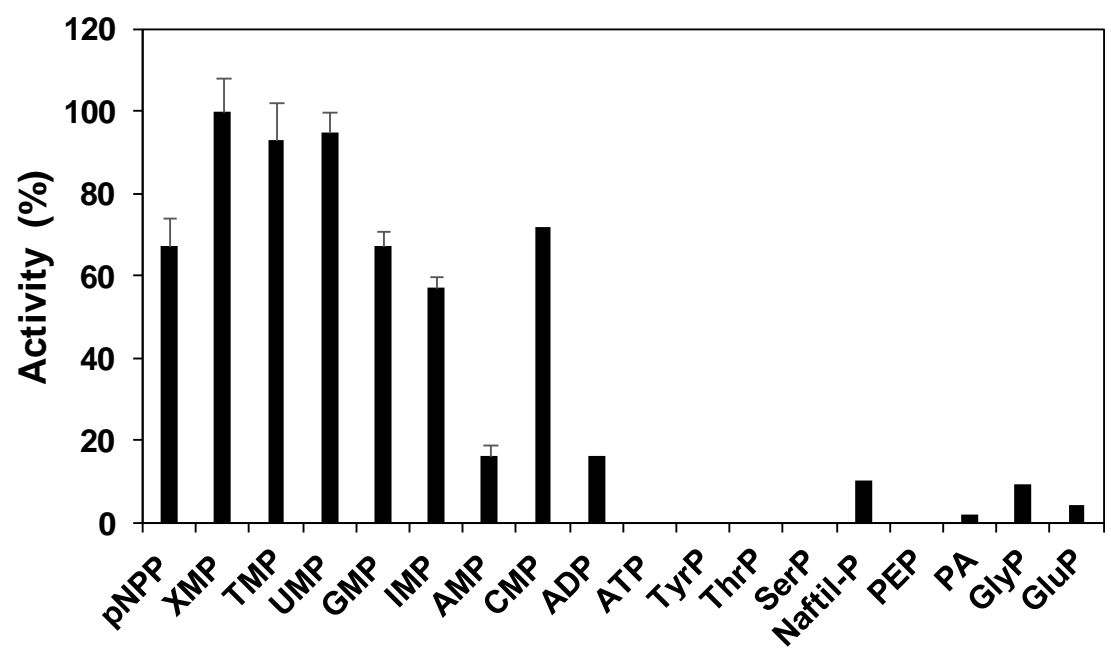

Figure 3. Phosphatase activity of purified PvNTD2 with several phosphorylated compounds. The activity was determined under standard assays with the compound indicated at a final concentration of $2 \mathrm{mM}$. One hundred percent corresponded to $4.1 \mathrm{U} / \mathrm{mg}$ protein. Values are mean $\pm \mathrm{SE}$ of three independent determinations.

The $\mathrm{K}_{\mathrm{m}}$ and $\mathrm{V}_{\max }$ values were calculated by Hanes-Woolf plots with nucleotides with high activity as well as with AMP (Table 1$)$. The $K_{m}$ value with AMP as substrate $(0.011 \mathrm{mM})$ was lower than that of the other nucleotides assayed, which ranged from $0.039 \mathrm{mM}$ for UMP to $0.095 \mathrm{mM}$ for XMP. The catalytic efficiency calculated as $V_{\max } / K_{m}$ was higher with AMP than with the other nucleotides.

Table 1. Kinetic properties of purified PvNTD2 with several nucleotides. Activity was assayed under standard conditions, and the values for $\mathrm{K}_{\mathrm{m}}$ and $\mathrm{V}_{\max }$ were calculated by Hanes-Woolf plots.

\begin{tabular}{cccc}
\hline Substrate & $\mathbf{K}_{\mathbf{m}}(\mathbf{m M})$ & $\mathbf{V}_{\max }(\mathbf{U} / \mathbf{m g})$ & $\mathbf{V}_{\max } / \mathbf{K}_{\mathbf{m}}$ \\
\hline AMP & 0.011 & 1.46 & 132 \\
UMP & 0.039 & 4.00 & 103 \\
TMP & 0.063 & 4.08 & 64 \\
XMP & 0.095 & 4.22 & 44 \\
\hline
\end{tabular}

The optimum $\mathrm{pH}$ with all the substrates analysed was between 7 and 7.5, with a marked decrease in activity at $\mathrm{pH}$ values below 6.5 or above 7.5 , with the exception of AMP (Figure 4). With AMP as substrate, the nucleotidase activity of the purified protein was very similar at $\mathrm{pH} 8.5$ and 7.5, and AMP was the only substrate with which the activity at $\mathrm{pH} 8.5$ was higher than that at $\mathrm{pH} 7$ (Figure 4).

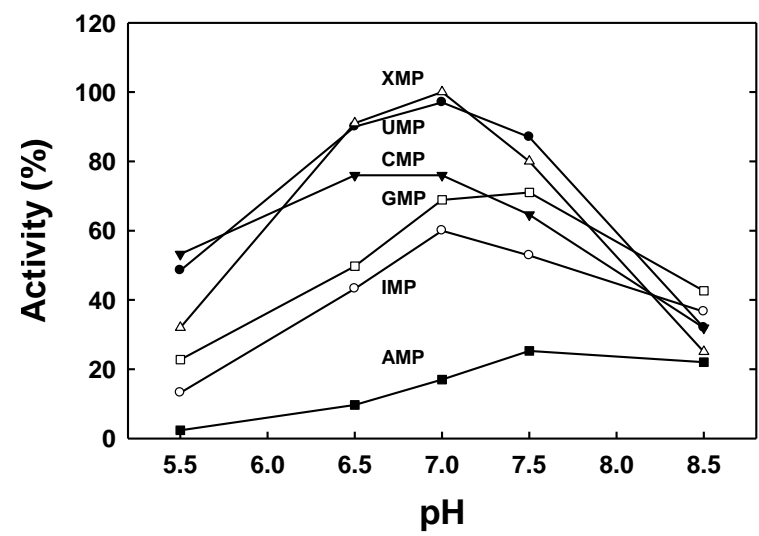

Figure 4. Effect of $\mathrm{pH}$ on the activity of PvNTD2 with several nucleotides as substrates. The activity was determined in $50 \mathrm{mM}$ MES-Tris buffer at the indicated $\mathrm{pH}$ values. 
The effect of several compounds on the phosphatase activity of the purified protein was determined at $\mathrm{pH}$ 7. The activity was insensitive to the inhibitors of unspecific acid phosphatases such as vanadate, molybdate, tartrate, or fluoride at a final concentration of $1 \mathrm{mM}$. Free phosphate $(0.1 \mathrm{mM})$, a product of the reaction, was assayed in the reaction with pNPP as substrate, and no effect was observed in the activity. The phosphatase activity was determined as well in the presence of several nucleosides, the other products of the reaction, at a final concentration of $0.2 \mathrm{mM}$ in the reaction mixture. The activity of the recombinant protein was strongly inhibited in the presence of adenosine (Figure 5A), and inhibition by adenosine was observed with all the nucleotides used as substrate in the assay (Figure 5B).

A

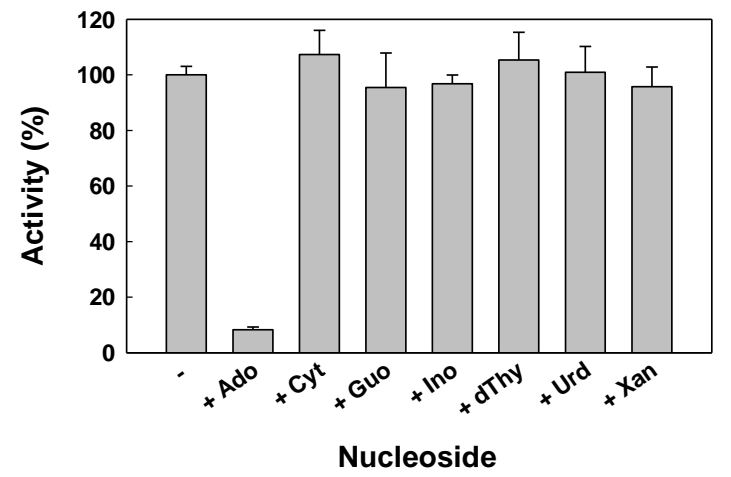

B

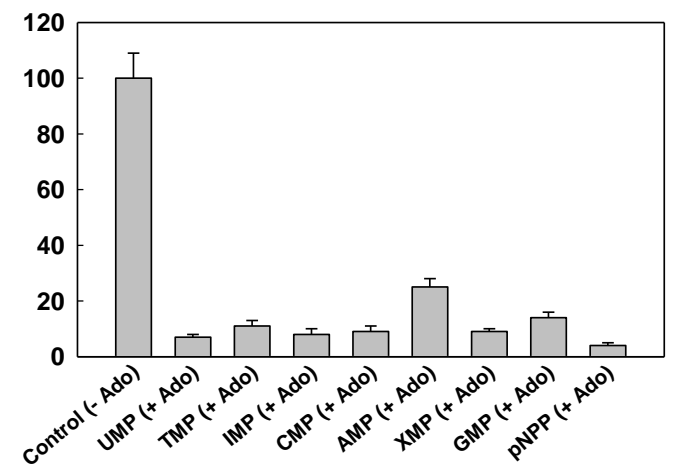

Figure 5. Effect of nucleosides on the activity of PvNTD2. (A) Phosphatase activity was determined with $2 \mathrm{mM}$ UMP as substrate in the absence of nucleoside (-) or in the presence of $0.2 \mathrm{mM}$ adenosine (+Ado), cytosine (+Cyt), guanosine (+Guo), inosine (+Ino), thymidine (+dThy), uridine (+Urd), or xanthosine (+Xan). The activity in the absence of nucleoside was considered as $100 \%$. (B) Effect of adenosine on the activity of PvNTD2 with several nucleotides as substrates. Phosphatase activity was determined with $2 \mathrm{mM}$ of nucleotide indicated in the absence or presence of $0.2 \mathrm{mM}$ adenosine. The activity with every nucleotide in the absence of nucleoside was normalised as $100 \%$ (control), and the corresponding activity in the presence of adenosine is represented for each nucleotide as substrate. Values are mean $\pm \mathrm{SE}$ of three independent determinations.

\subsection{Gene Expression}

Expression level of PvNTD2 was analysed in several tissues from common bean plants including cotyledons and embryonic axes from seedlings, different tissues from twenty-eight-day-old nodulated common bean plants (in the vegetative stage), and in pods of plants in the reproductive stage (Figure 6). PvNTD2 transcript was particularly high in nodules, whereas it reached similar levels in all the other tissues. 


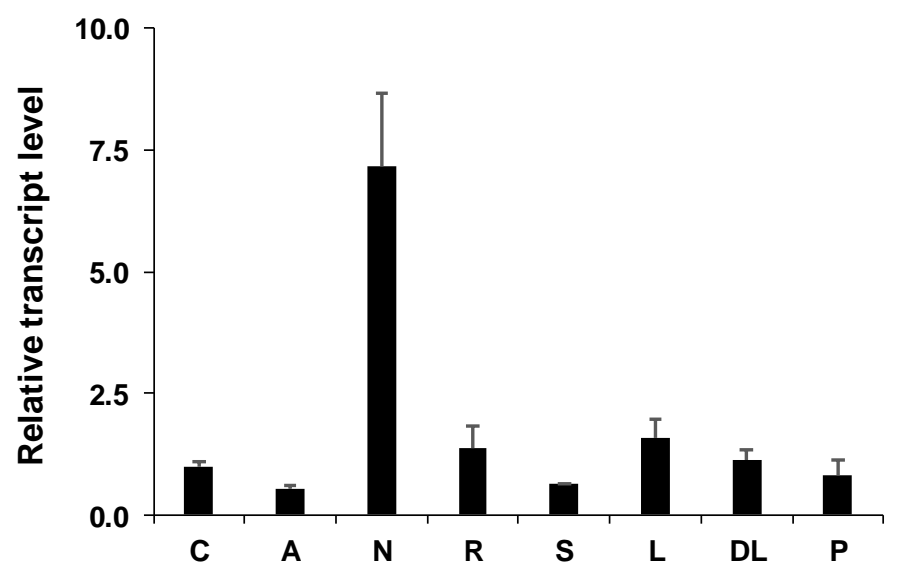

Figure 6. Expression pattern of PvNTD2 in different tissues of Phaseolus vulgaris plants. The relative expression level was normalised using a geometric mean of two reference genes. Cotyledons $(\mathrm{C})$ and embryonic axes (A) from seedlings at $5 \mathrm{~d}$ of development, nodules $(\mathrm{N})$, roots $(\mathrm{R})$, stems $(\mathrm{S})$, mature leaves (L), developing leaves (DL), and mature pods (P) from adult plants. Values are mean \pm SE of three independent experiments.

The expression of PvNTD2 was analysed in physiological conditions with high nutrient mobilization such as embryonic axes development and leaf development (Figure 7). The expression of PvNTD2 increased significantly at 3 days after imbibition (DAI) in whole embryonic axes during germination and postgerminative growth (Figure 7A), whereas it remained very similar during leaf ontogeny (Figure 7B).

A

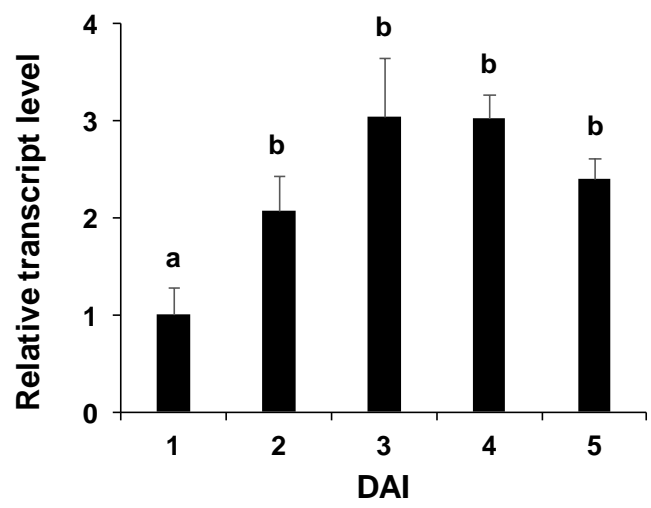

B

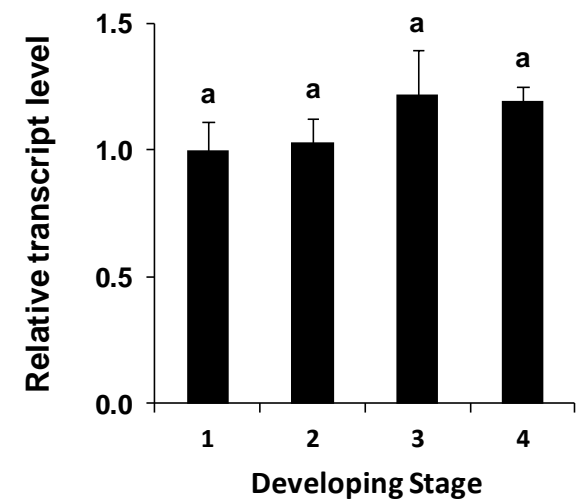

Figure 7. Expression pattern of PvNTD2 in different nutrient mobilization processes. (A) PvNTD2 gene expression analysis was performed using qRT-PCR on total RNA samples extracted from embryonic axes of the common bean at the days after imbibition (DAI) indicated. (B) Relative expression levels of PvNTD2 during leaf ontogeny. The fourth trifoliate leaves were obtained from plants at the vegetative stage and classified according to the length of the middle leaflet: stage $1(5-20 \mathrm{~cm})$, stage $2(20-40 \mathrm{~cm})$, stage $3(40-60 \mathrm{~cm})$, and stage 4 (more than $60 \mathrm{~cm}$ ). Different letters indicate statistically significant differences according to Bonferroni analysis $(p \leq 0.05)$.

Since the expression of PvNTD2 was higher in nodules than in all the other tissues, we analysed its expression during nodules development and compared its expression to that of PvNTD1 (Figure 8). PvNTD2 was expressed at higher levels and presented a different expression pattern than PvNTD1 in this organ. PvNTD1 expression was higher in immature nodules and decreased during nodule development, whereas that of PvNTD2 was similar during all the developing stages analysed (Figure 8). 


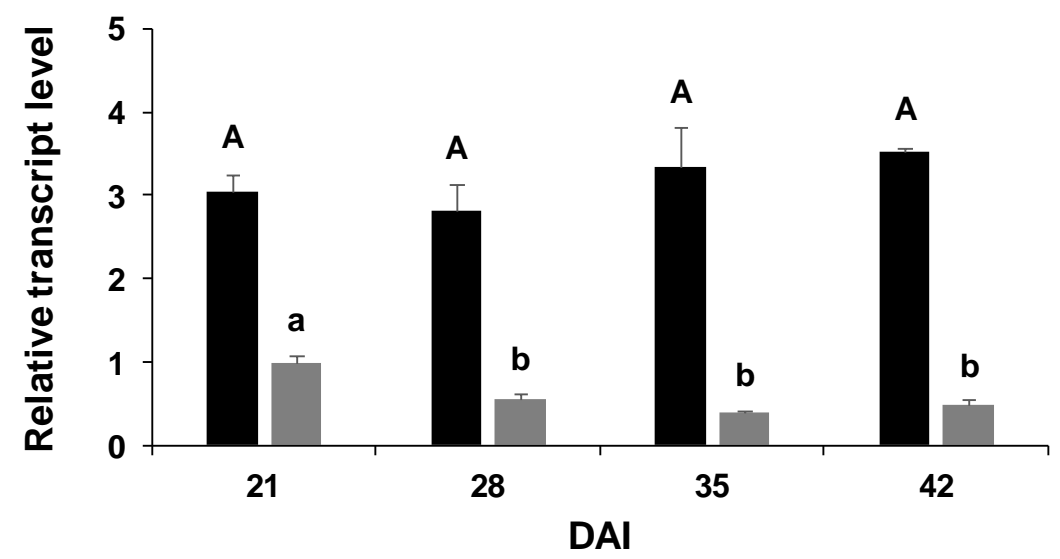

Figure 8. Expression patterns of PvNTD1 (grey) and PvNTD2 (black) during the development of nodules of the common bean. The relative expression level was normalised using a geometric mean of two reference genes. Values are mean \pm SE of three biological replicates, with three technical replicates per experiment. All the values were normalised to the values of PvNTD1 expression at 21 days after inoculation. Difference letters indicate statistically significant differences according to Bonferroni analysis $(p \leq 0.05)$.

\section{Discussion}

Despite the advantages of genome sequencing, it is not clear which gene or genes are responsible for encoding the protein or proteins involved in dephosphorylation of nucleotides. It is also unknown if the enzyme or enzymes show specificity for some nucleotides, if they can distinguish between purines or pyrimidines, or if they can dephosphorylate in vivo all the nucleotides. PvNTD2 was identified as the gene from common bean with the highest identity to the previously identified and characterised PvNTD1 [13]. PvNTD2 has the characteristic domains of the HAD (haloacid dehalogenase-like hydrolases) superfamily, which includes, among other proteins, hydrolases, phosphatases, nucleotidases, and several phosphotransferases [11]. Apart from these motifs, the members of the HAD superfamily have a high sequence divergence, and the catalysed reactions and substrate specificities are difficult to predict and must be determined empirically [28]. PvNTD2 encodes a protein that can use both purine and pyrimidine nucleotides as substrate.

PvNTD1 shares some characteristics with PvNTD2. Both are insensitive to molybdate, a common inhibitor of acid phosphatases [14], have reduced activity with AMP as substrate compared to the other nucleotides, and are specifically inhibited by adenosine. Although this feature is shared with PvNTD1, the inhibition was higher in PvNTD2 than in PvNTD1 [13]. PvNTD2 also shared with PvNTD1 the tendency to form reducing-resistant dimers. Western blot analysis revealed the possibility of PvNTD2 forming dimers in reducing SDS-PAGE, and this behaviour was observed as well in plant-purified PvNTD1, which required urea treatment to fully denature the protein to monomers $[12,13]$.

Nucleotide synthesis by salvage pathways is energetically favourable for cells; therefore, if bases or nucleosides are abundant, these are recycled to synthesise nucleotides. In plant cells, the levels of free nucleosides and bases are much lower than those of nucleotides [29]. It has been postulated that the balance between synthesis and degradation of nucleotides could be regulated by the ratio between phosphatase and kinase activities [11]. If the kinase predominates against the phosphatase, the synthesis of nucleotides would be favoured against degradation, resulting in anabolic processes instead of catabolic. Our results suggest that adenosine could have a crucial role in this balance, inhibiting the degradation of nucleotides when its concentration increases. The kinetic constants also could support this role for AMP/adenosine. Among the substrates analysed, a higher affinity was found for AMP, with a low value of $K_{m}$ and high catalytic efficiency $\left(V_{\max } / K_{m}\right)$, than with the nucleotides with the highest specific activity (UMP, TMP, and XMP). 
Nucleotidases can be involved in processes in which purine nucleotide metabolism can have a role for nutrient mobilization such as seeding [2,3] or leaf [4] development. A source for nucleotides can be nucleic acids, compounds that, during nutrient mobilization, must be degraded to relocate the degradation products to the new developing tissues. The expression of PvNTD2 was induced in embryonic axes in concordance to the increase in nuclease $[3,30]$ and nucleotidase activities, and PvNTD1 expression [13], suggesting that both nucleotidases participate coordinately in this process. During leaf ontogeny, clear differences in the expression of PvNTD1 and PvNTD2 were found: PvNTD1 expression was high in young leaves and decreased during leaf ontogeny [13], whereas the expression of PvNTD2 was maintained during the whole process (Figure 7), suggesting different roles for both proteins.

The expression of PvNTD2 was higher in nodules than in the rest of the tissues. The common bean is a ureidic legume that transports the fixed nitrogen to the upper part of the plant as ureides. Ureides are synthesized from the catabolism of purines; therefore, one or several nucleotidase/s must be involved [1]. The high expression of PvNTD2 in nodules could suggest a role of PvNTD2 in ureide synthesis. However, its expression pattern in nodules does not correlate with the pattern of nitrogen fixation in common bean [31]. Nevertheless, we cannot discard a role of PvNTD2 in de novo ureides synthesis, since this lack of strict correlation has been also observed for the first enzyme committed to de novo ureides synthesis in nodules [31]. Two phosphatase activities purified from nodules from ureidic legumes have been reported: one of common bean [32] and another one of soybean [15]. PvNTD2 is clearly a different protein with a different activity than that purified by Garcia and colleagues from common bean [32], since the latter has a molecular weight of $120 \mathrm{kDa}$ and is sensitive to molybdate. On the other side, the enzyme from soybean is a $70 \mathrm{kDa}$ protein whose behaviour in the presence of molybdate is not reported [15]. The authors indicated that the soybean protein is the $5^{\prime}$-nucleotidase involved in the conversion of nucleotides to nucleosides in the pathway leading to ureide synthesis in nodules. The activity of the soybean enzyme with pyrimidine nucleotides was not reported, and it was similar with all the purine nucleotides tested, including AMP $[15,16]$. PvNTD2 can hydrolyse both purine and pyrimidine nucleotides with similar in vitro activity, with the exception of AMP. PvNTD2 shows some identity with the gene encoding the enzyme purified in soybean; nevertheless, in this organism, there are other sequences with higher identity to PvNTD2 (Table S1), which suggests that PvNTD2 and the gene encoding the nodule soybean nucleotidase are not orthologous. Furthermore, PvNTD2 was predicted to be in the apoplast, which does not seem to fit with a role as the main enzyme involved in ureide biosynthesis. However, the probability of this location is 0.73 , and DeepLoc prediction has an accuracy of $78 \%$ so that another location cannot be totally discarded. A different function to ureide biosynthesis during nitrogen fixation is also plausible.

Nitrogen-fixing legumes demand more $P$ than non-nodulating plants for optimal functioning, and under P deficiency, the growth of these nitrogen-fixing legumes is retarded [33]. It has been proposed that the level of $\mathrm{P}$ in the nodules is determinant for the symbiotic efficiency, and several mechanisms have been proposed for the maintenance of P in nodules [33]. Therefore, PvNTD2 could play a role supplying $P$ to the nodule to fulfil this special requirement.

To summarize, the nucleotidase described in this work can use in vitro all the nucleoside monophosphates as substrate, and it is insensitive to molybdate. In addition, PvNTD2 is expressed in situations with high nucleotide metabolism. All of this supports the role of this protein as a nucleotidase. Like PvNTD1, PvNTD2 is expressed in all the tissues analysed, although the expression pattern of both genes shows clear differences, mainly in leaf ontogeny and nodules. The high expression of PvNTD2 in nodules and its maintenance during development in contraposition to PvNTD1 expression, which levels are lower and decrease during nodule development, support a different role for both PvNTD1 and PvNTD2 in nodules of the common bean. Whether this role is related to the de novo synthesis of ureides or not needs further investigation. 


\section{Materials and Methods}

\subsection{Plant Material and Growth Condition}

Common bean (Phaseolus vulgaris L. cv. Great Northern) seeds were sterilised in ethanol (30 s) and sodium hypochlorite $0.2 \%(w / v)(5 \mathrm{~min})$. The surface-sterilised seeds were washed repeatedly with distilled water and then placed in Petri dishes (120 mm diameter) with wet paper in sterile conditions.

The material from seedlings up to $6 \mathrm{~d}$ after start of imbibition were obtained from seedlings maintained in the Petri dishes with regular addition of distilled water. To obtain the material from adult plants, germinated seedlings were sown on pots $3 \mathrm{~d}$ after imbibition, and the plants were inoculated with Rhizobium leguminosarum ISP14 and cultivated and maintained as indicated elsewhere [34]. The following samples were collected from plants after $28 \mathrm{~d}$ of growth: roots after careful removal of nodules, mature and immature leaves, and shoots after removal of leaves and nodules. The flowers and pods were obtained from plants in the reproductive stage. Studies during the development of the leaves and nodules were performed as described [34].

\subsection{Cloning into the $p E T 30 b(+)$ Expression Vector}

The coding region of PvNTD2 cDNA lacking the signal peptide was obtained by PCR from cDNA from senescing leaves from common bean using the primers NTD400Pv01 and NTD400Pv02 containing restriction sites for $\mathrm{NcoI}$ and XhoI, respectively (Table S2). The PCR product was cloned and transformed into Escherichia coli $\mathrm{DH} 5 \alpha \mathrm{F}^{\prime}$. The insert was digested with $N$ coI and XhoI, cloned into the vector pET30b(+), and transformed into E. coli BL21 (DE3) cells (Novagen). The pET30b(+) allows the expression of the recombinant protein fused to a His tag at both ends. The final construct was sequenced to confirm the absence of mutations.

\subsection{Expression and Purification of the Recombinant Protein}

The transformed cells were grown in $200 \mathrm{~mL}$ of LB medium supplemented with $50 \mathrm{mg} / \mathrm{L}$ kanamycin at $37^{\circ} \mathrm{C}$ until an absorbance of 0.5 at $600 \mathrm{~nm}$ was reached. Isopropyl- $\beta$-D-thiogalactopyranoside (IPTG) was added at a final concentration of $1 \mathrm{mM}$ to the cultures, and the expression of the heterologous protein was induced at $37^{\circ} \mathrm{C}$ for $2 \mathrm{~h}$. Afterwards, the cells were harvested by centrifugation at 2000× $g$ and $4{ }^{\circ} \mathrm{C}$ for $10 \mathrm{~min}$, and the pellet was stored at $-20^{\circ} \mathrm{C}$.

The pellet was resuspended in $4 \mathrm{~mL}$ of lysis buffer (50 mM TRIS-HCl (pH 7.8), $1 \mathrm{mM} \mathrm{MgCl}$, $150 \mathrm{mM} \mathrm{NaCl}, 0.02 \%(v / v)$ Tween 20, and 10\% (v/v) glycerol), and cells were lysed by sonication on a Vibra Cell (Sonics and Materials Inc., Newton, MA, USA) using 3 pulses of $90 \mathrm{~W}$ and $5 \mathrm{~s}$ each, keeping the samples on ice. After sonication, the homogenate was centrifuged at $12000 \times g$ for $15 \min$ at $4{ }^{\circ} \mathrm{C}$. The supernatant was used as crude extract for further purification. The pellet was resuspended in $4 \mathrm{~mL}$ of lysis buffer to analyse the insoluble fraction corresponding to inclusion bodies. The crude extract was passed through a Nickel Chelating Sepharose column (1 mL, GE Healthcare, Uppsala, Sweden) equilibrated with lysis buffer. The column was washed with $5 \mathrm{~mL}$ of lysis buffer, followed by a second wash with $5 \mathrm{~mL}$ of lysis buffer supplemented with $25 \mathrm{mM}$ imidazole. The protein was eluted with 3 $\mathrm{mL}$ of the same buffer supplemented with $200 \mathrm{mM}$ imidazole.

\subsection{Gel Electrophoresis, Western Blot Analysis, and Protein Stain}

Proteins were mixed with denaturing buffer and boiled for $5 \mathrm{~min}$ and fractionated in $10 \%$ SDS-PAGE gels by using a Mini PROTEAN III system (Bio-Rad). After separation, proteins were electro-transferred to a polyvinylidene fluoride (PVDF) membrane (Sigma-Aldrich, St Louis, MI, USA). To detect His-tagged protein, blots were incubated with a monoclonal anti-polyhistidine antibody (H1029, Sigma-Aldrich) at 1:10,000. Anti-mouse IgG, alkaline phosphatase conjugated (A3562, Sigma-Aldrich), was used as secondary antibody at a 1:12,500 dilution, and the immunoreaction was developed with 5-bromo-4-chloro-3-indolyl phosphate p-toluidine salt (125 mg mL $\left.{ }^{-1}\right)$ and nitro-blue 
tetrazolium chloride $\left(250 \mathrm{mg} \mathrm{mL}^{-1}\right)$ as substrates. Silver staining was performed using the Silver Staining kit (Sigma-Aldrich).

\subsection{Enzymatic Activity}

Phosphatase activity was determined as previously indicated [12]. The phosphatase activity was calculated as the production of phosphate along time in reaction mixtures with several phosphorylated compounds. Unless otherwise stated, the standard reaction mixture for recombinant PvNTD2 purified from E. coli contained $50 \mathrm{mM}$ TES- $\mathrm{NaOH}$ ( $\mathrm{pH}$ 7), $1 \mathrm{mM} \mathrm{MgCl} 2,2 \mathrm{mM}$ substrate, and an adequate amount of enzyme. The reactions were initiated by the addition of the enzyme and were performed at $37^{\circ} \mathrm{C}$. Aliquots of $0.2 \mathrm{~mL}$ were extracted several times, and the amount of phosphate was determined. One unit of enzyme is defined as the amount of enzyme that catalyses the formation of $1 \mu \mathrm{mol}$ of phosphate per minute.

\subsection{RNA Isolation and cDNA Synthesis}

Total RNA was isolated from several tissues using the NZYol Reagent (NZYTECH) according to the manufacturer's instructions, except that an additional $\mathrm{LiCl}$ precipitation step was included at the end to improve the RNA quality. A $2 \mu \mathrm{g}$ sample of total RNA was treated with RNAase-free DNAseI (NEB) at $37^{\circ} \mathrm{C}$ for $30 \mathrm{~min}$ to eliminate any traces of genomic DNA. First-strand cDNA synthesis was performed with DNAse-treated RNA using a Revert Aid reverse transcriptase (ThermoFisher) with random hexamer primers.

\subsection{Real-Time PCR}

Quantitative RT-PCR (qRT-PCR) was carried out with an iCycler iQ system using the iQ SYBRGreen supermix (Bio-Rad) and the gene-specific primers specified in Table S2. The PCR program consisted of an initial denaturation of $5 \mathrm{~min}$ at $95^{\circ} \mathrm{C}$, followed by 40 cycles of $15 \mathrm{~s}$ at $95^{\circ} \mathrm{C}, 30 \mathrm{~s}$ at $60{ }^{\circ} \mathrm{C}$, and $30 \mathrm{~s}$ at $72{ }^{\circ} \mathrm{C}$. After the final cycle, a melting curve analysis was performed over a temperature range of $60-100{ }^{\circ} \mathrm{C}$ by increments of $0.5{ }^{\circ} \mathrm{C}$ in order to verify the reaction specificity. Results were normalised using the geometric mean of two control genes (ubiquitin and actin-2) using the $2^{-\Delta \Delta C T}$ method [35].

\subsection{Analytical Determination}

Protein concentration was determined by the Bradford method [36] using bovine serum albumin as standard and the Bio-Rad system.

\subsection{Statistical Analyses}

All results are means of three independent experiments with three technical replicates per experiment. Values are mean \pm SE. Statistical analyses were performed with SPSS Statistics, version 17.0, using unifactorial ANOVAs. Homoscedasticity was determined using the Levene test, and Bonferroni statistics were applied for variables with homogeneity of variance.

Supplementary Materials: The following are available online at http://www.mdpi.com/2223-7747/9/2/171/s1, Table S1: Sequences with the highest homology after searching in NCBI database using tblastn, Table S2: Primers used in this study.

Author Contributions: Conceptualization, P.P. and G.G.-V.; methodology, G.G.-V., F.A.Q., and P.P.; validation, G.G.-V., F.A.Q., and P.P.; formal analysis, G.G.-V., and P.P.; investigation, G.G.-V., E.D.-G., M.D.-B., O.M., and F.A.Q.; data curation G.G.-V., and P.P.; writing — original draft preparation, P.P.; writing—review and editing, G.G.-V. and M.P.; funding acquisition, G.G.-V., M.P., and P.P. All authors have read and agreed to the published version of the manuscript.

Funding: This work was supported by Ministerio de Economía y Competitividad (AGL2015-69554) and Plan Andaluz de Investigación (BIO115).

Acknowledgments: The authors thank Marta Robles for her technical assistance, Juan M. Cabello-Diaz for his help at the start of the work, and Alfonso Muñoz for his critical reading of the manuscript. E. Delgado-Garcia 
acknowledges the support of a contract from Sistema Nacional de Garantía Juvenil and the Programa Operativo de Empleo Juvenil (Junta de Andalucía y Fondo Social Europeo). M Diaz-Baena acknowledges the support of fellowship from Universidad de Córdoba (Beca Semillero) and Ministerio de Educación Cultura y Deporte (Beca de Colaboración).

Conflicts of Interest: The authors declare no conflict of interest. The funders had no role in the design of the study; in the collection, analyses, or interpretation of data; in the writing of the manuscript, or in the decision to publish the results.

\section{References}

1. Zrenner, R.; Stitt, M.; Sonnewald, U.; Boldt, R. Pyrimidine and purine biosynthesis and degradation in plants. Annu. Rev. Plant Biol. 2006, 57, 805-836. [CrossRef] [PubMed]

2. Quiles, F.A.; Raso, M.J.; Pineda, M.; Piedras, P. Ureide metabolism during seedling development in French bean (Phaseolus vulgaris). Physiol. Plant 2009, 135, 19-28. [CrossRef] [PubMed]

3. Lambert, R.; Cabello-Diaz, J.M.; Quiles, F.A.; Piedras, P. Identification of nucleases related to nutrient mobilization in senescing cotyledons from French bean. Acta Physiol. Plant 2016, 38, 266. [CrossRef]

4. Lambert, R.; Quiles, F.A.; Galvez-Valdivieso, G.; Piedras, P. Nucleases activities during French bean leaf aging and dark-induced senescence. J. Plant Physiol. 2017, 218, 235-242. [CrossRef] [PubMed]

5. Brychkova, G.; Alikulov, Z.; Fluhr, R.; Sagi, M. A critical role for ureides in dark and senescence-induced purine remobilization is unmasked in the Atxdh1 Arabidopsis mutant. Plant J. 2008, 54, 496-509. [CrossRef] [PubMed]

6. Irani, S.; Todd, C.D. Ureide metabolism under abiotic stress in Arabidopsis thaliana. J. Plant Physiol. 2016, 199, 87-95. [CrossRef]

7. Irani, S.; Todd, C.D. Exogenous allantoin increases Arabidopsis seedlings tolerance to $\mathrm{NaCl}$ stress and regulates expression of oxidative stress response genes. J. Plant Physiol. 2018, 221, 43-50. [CrossRef]

8. Watanabe, S.; Matsumoto, M.; Hakomori, Y.; Takagi, H.; Shimada, H.; Sakamoto, A. The purine metabolite allantoin enhances abiotic stress tolerance through synergistic activation of abscisic acid metabolism. Plant Cell Environ. 2014, 37, 1022-1036. [CrossRef]

9. Quiles, F.A.; Galvez-Valdivieso, G.; Guerrero-Casado, J.; Pineda, M.; Piedras, P. Relationship between ureidic/amidic metabolism and antioxidant enzymatic activities in legume seedlings. Plant Physiol. Biochem. 2019, 138, 1-8. [CrossRef]

10. Atkins, C.A.; Smith, P.M.C. Ureide synthesis in legume nodules. In Prokaryotic Nitrogen Fixation: A Model System for the Analysis of a Biological Process; Triplett, E.W., Ed.; Horizon Scientific Press: Norfolk, UK, 2000; pp. 559-587.

11. Bogan, K.L.; Brenner, C. 5'-nucleotidases and their new roles in $\mathrm{NAD}^{(+)}$and phosphate metabolism. New J. Chem. 2010, 34, 845-853. [CrossRef]

12. Cabello-Díaz, J.M.; Quiles, F.A.; Lambert, R.; Pineda, M.; Piedras, P. Identification of a novel phosphatase with high affinity for nucleotides monophosphate from common bean (Phaseolus vulgaris). Plant Physiol. Biochem. 2012, 53, 54-60. [CrossRef] [PubMed]

13. Cabello-Diaz, J.M.; Galvez-Valdivieso, G.; Caballo, C.; Lambert, R.; Quiles, F.A.; Pineda, M.; Piedras, P. Identification and characterization of a gene encoding for a nucleotidase from Phaseolus vulgaris. J. Plant Physiol. 2015, 185, 44-51. [CrossRef] [PubMed]

14. Duff, S.M.G.; Sarath, G.; Plaxton, W.C. The role of acid phosphatases in plant phosphorus metabolism. Physiol. Plant. 1994, 90, 791-800. [CrossRef]

15. Penheiter, A.R.; Duff, S.M.G.; Sarath, G. Soybean root nodule acid phosphatase. Plant Physiol. 1997, 114, 597-604. [CrossRef] [PubMed]

16. Penheiter, A.R.; Klucas, R.V.; Sarath, G. Purification and characterization of a soybean root nodule phosphatase expressed in Pichia pastoris. Protein Expres. Purif. 1998, 14, 125-130. [CrossRef]

17. Veljanovski, V.; Major, I.T.; Patton, J.J.; Bol, E.; Louvet, S.; Hawkins, B.J.; Constabel, C.P. Induction of acid phosphatase transcripts, protein and enzymatic activity by simulated herbivory of hybrid poplar. Phytochemistry 2010, 71, 619-626. [CrossRef]

18. Liu, Y.L.; Ahn, J.E.; Datta, S.; Salzman, R.A.; Moon, J.; Huyghues-Despointes, B.; Pittendrigh, B.; Murdock, L.L.; Koiwa, H.; Zhu-Salzman, K. Arabidopsis vegetative storage protein is an anti-insect acid phosphatase. Plant Physiol. 2005, 139, 1545-1556. [CrossRef] 
19. Gohla, A. Do metabolic HAD phosphatases moonlight as protein phosphatases? BBA-Mol. Cell Res. 2019, 1866, 153-166. [CrossRef]

20. Seifried, A.; Schultz, J.; Gohla, A. Human HAD phosphatases: Structure, mechanism, and roles in health and disease. FEBS J. 2013, 280, 549-571. [CrossRef]

21. Baldwin, J.C.; Karthikeyan, A.S.; Cao, A.; Raghothama, K.G. Biochemical and molecular analysis of LePS2;1: A phosphate starvation induced protein phosphatase gene from tomato. Planta 2008, 228, 273-280. [CrossRef]

22. Liang, C.Y.; Chen, Z.J.; Yao, Z.F.; Tian, J.; Liao, H. Characterization of two putative protein phosphatase genes and their involvement in phosphorus efficiency in Phaseolus vulgaris. J. Integr. Plant Biol. 2012, 54, 400-411. [CrossRef] [PubMed]

23. Pandey, B.K.; Mehra, P.; Verma, L.; Bhadouria, J.; Giri, J. OsHAD1, a haloacid dehalogenase-like APase, enhances phosphate accumulation. Plant Physiol. 2017, 174, 2316-2332. [CrossRef] [PubMed]

24. Basic Local Alignment Search Tool. Available online: https://blast.ncbi.nlm.nih.gov/Blast.cgi (accessed on 19 June 2019).

25. Armenteros, J.J.A.; Tsirigos, K.D.; Sonderby, C.K.; Petersen, T.N.; Winther, O.; Brunak, S.; von Heijne, G.; Nielsen, H. SignalP 5.0 improves signal peptide predictions using deep neural networks. Nat. Biotechnol. 2019, 37, 420-423. [CrossRef] [PubMed]

26. Armenteros, J.J.A.; Sonderby, C.K.; Sonderby, S.K.; Nielsen, H.; Winther, O. DeepLoc: Prediction of protein subcellular localization using deep learning. Bioinformatics 2017, 33, 3387-3395. [CrossRef]

27. Burroughs, A.M.; Allen, K.N.; Dunaway-Mariano, D.; Aravind, L. Evolutionary genomics of the HAD superfamily: Understanding the structural adaptations and catalytic diversity in a superfamily of phosphoesterases and allied enzymes. J. Mol. Biol. 2006, 361, 1003-1034. [CrossRef]

28. Kuznetsova, E.; Proudfoot, M.; Gonzalez, C.F.; Brown, G.; Omelchenko, M.V.; Borozan, I.; Carmel, L.; Wolf, Y.I.; Mori, H.; Savchenko, A.V.; et al. Genome-wide analysis of substrate specificities of the Escherichia coli haloacid dehalogenase-like phosphatase family. J. Biol. Chem. 2006, 281, 36149-36161. [CrossRef]

29. Stasolla, C.; Katahira, R.; Thorpe, T.A.; Ashihara, H. Purine and pyrimidine nucleotide metabolism in higher plants. J. Plant Physiol. 2003, 160, 1271-1295. [CrossRef]

30. Lambert, R.; Quiles, F.A.; Cabello-Diaz, J.M.; Piedras, P. Purification and identification of a nuclease activity in embryo axes from French bean. Plant Sci. 2014, 224, 137-143. [CrossRef]

31. Coleto, I.; Trenas, A.T.; Erban, A.; Kopka, J.; Pineda, M.; Alamillo, J.M. Functional specialization of one copy of glutamine phosphoribosyl pyrophosphate amidotransferase in ureide production from symbiotically fixed nitrogen in Phaseolus vulgaris. Plant Cell Environ. 2016, 39, 1767-1779. [CrossRef]

32. Garcia, N.A.T.; Olivera, M.; Iribarne, C.; Lluch, C. Partial purification and characterization of a non-specific acid phosphatase in leaves and root nodules of Phaseolus vulgaris. Plant Physiol. Biochem. 2004, 42, 585-591. [CrossRef]

33. Sulieman, S.; Tran, L.S.P. Phosphorus homeostasis in legume nodules as an adaptive strategy to phosphorus deficiency. Plant Sci. 2015, 239, 36-43. [CrossRef]

34. Galvez-Valdivieso, G.; Alamillo, J.M.; Fernandez, J.; Pineda, M. Molecular characterization of PVAS3: An asparagine synthetase gene from common bean prevailing in developing organs. J. Plant Physiol. 2013, 170, 1484-1490. [CrossRef] [PubMed]

35. Livak, K.J.; Schmittgen, T.D. Analysis of relative gene expression data using real-time quantitative PCR and the 2(-Delta Delta C(T)) method. Methods 2001, 25, 402-408. [CrossRef] [PubMed]

36. Bradford, M.M. Rapid and sensitive method for quantitation of microgram quantities of protein utilizing principle of protein-dye binding. Anal. Biochem. 1976, 72, 248-254. [CrossRef]

(C) 2020 by the authors. Licensee MDPI, Basel, Switzerland. This article is an open access article distributed under the terms and conditions of the Creative Commons Attribution (CC BY) license (http://creativecommons.org/licenses/by/4.0/). 